\title{
Acidobacteria: 'n Bakteriële groep van belang in die Suid-Afrikaanse fynbosbioom
}

\author{
Outeurs: \\ Tersia A Conradie \\ $\mathrm{K}$ Jacobs \\ Affiliasie: \\ Departement Mikrobiologie, \\ Universiteit van \\ Stellenbosch, \\ Privaatsak X1, Stellenbosch, \\ 7602 , Suid-Afrika \\ Korresponderende outeur: \\ Tersia Conradie \\ E-pos: tcon@sun.ac.za \\ Hoe om hierdie artikel aan \\ te haal: \\ Tersia A Conradie, K Jacobs, \\ Acidobacteria: 'n Bakteriële \\ groep van belang in \\ die Suid-Afrikaanse \\ fynbosbioom, Suid- \\ Afrikaanse Tydskrif vir \\ Natuurwetenskap en \\ Tegnologie 39(1) (2020). \\ https://doi.org/10.36303/ \\ SATNT.2020.39.1.811 \\ Kopiereg: \\ (C) 2020. Authors. \\ Licensee: Die Suid- \\ Afrikaanse Akademie vir \\ Wetenskap en Kuns. \\ Hierdie werk is onder \\ die Creative Commons \\ Attribution License \\ gelisensieer.
}

Acidobacteria: A bacterial group of interest in the South African fynbos biome: The commercialisation of plants can lead to a decrease in bacterial diversity. This study focused on the natural and commercial acidobacterial communities of two commercially important plants of South Africa, namely Aspalathus linearis (rooibos) and Cyclopia spp. (honeybush) and the effect of commercialisation on their relative abundance and diversity.

Aan die begin van die $21^{\text {ste }}$ eeu het die toepassing van molekulêre tegnieke 'n nuwe en opwindende wêreld vir wetenskaplikes oopgemaak. Hierdie tegnieke het gelei tot die ontdekking van groot hoeveelhede onbekende mikroörganismes regoor die wêreld wat aan die filum Acidobacteria behoort. Hierdie groep het in 1997 filumstatus ontvang met slegs drie gekweekte verteenwoordigers en vier hoofsubgroepe waarvan elke subgroep ooreenstem met 'n klas. Hierdie filum is vernoem na die eerste gekweekte verteenwoordiger, Acidobacterium capsulatum. Sedertdien het die aantal subgroepe toegeneem na 26 met ongeveer 60 gekweekte verteenwoordigers. Hierdie groep bakterieë kom algemeen in die grond voor, maar kan ook gevind word in varswatersediment, warmwaterbronne, suurmynmere en vele ander habitatte. Die Acidobacteria kom veral voor in grond met ' $\mathrm{n}$ lae $\mathrm{pH}$ en lae voedingstoflading. Daarom is die fynbosbioom van Suid-Afrika die ideale habitat vir Acidobacteria.

Die Kaapse Floristiese Streek (KFS) in die westelike en suid-westelike streke van Suid-Afrika is internasionaal bekend vir sy endemiese plantspesiediversiteit. Hierdie streek word gekenmerk deur 'n warm en matige klimaat met koel, nat winters en warm, droë somers. Sommige streke binne die KFS ervaar klein, maar beduidende hoeveelhede reënval in die droë somerseisoen. Die KFS het die rykste flora ter wêreld, aangesien dit byna 9000 plantspesies bevat op net $4 \%$ van Suid-Afrika se oppervlakte. Van die beraamde 9000 spesies, is ongeveer 7500 fynbosspesies. Twee fynbos peulgewasspesies, Aspalathus linearis en Cyclopia spp., behoort aan die Fabaceae-familie en word onder andere gebruik vir die maak van kruietee wat algemeen bekend staan as rooibostee (Aspalathus linearis) en heuningbostee (Cyclopia spp.). Die kommersialisering van plante lei gewoonlik tot ' $\mathrm{n}$ afname in die mikrobiese struktuur en diversiteit in die grond. Dit is hoofsaaklik as gevolg van landboupraktyke, gewastipe en seisoenale variasies. Die invloed van kommersialisering van rooibos en heuningbos op die Acidobacteria is nog nie deeglik bestudeer nie. Daarom was die doel om te kyk na die relatiewe verskeidenheid en oorvloed van Acidobacteria in die grond van twee Suid-Afrikaanse gewasse wat kommersieel belangrik is, naamlik rooibos (Aspalathus linearis) en heuningbos (Cyclopia spp.), in beide die natuurlike en kommersiële omgewings.

Met die gebruik van Mothur (v1.41.3) en die nuutste SILVA verwysingsprofiel, is die 16S rRNS geenvolgordes van beide natuurlike en kommersiële risosfeer rooibos- en heuningbosgrondmonsters ontleed. Die Acidobacteria geenvolgordes is afsonderlik van die res van die monster ontleed. In die heuningbosgrond is gevind dat sommige genera beduidend minder in oorvloed is in die natuurlike grond in vergelyking met die kommersiële grond. In teenstelling was daar ' $\mathrm{n}$ beduidende afname van sommige genera in die kommersiële rooibosgrond in vergelyking met die natuurlike grond. Die dominante subgroepe, teenwoordig in alle grondmonsters, was subgroep 1, 2 en 3. Hierdie subgroepe kom algemeen voor in die meeste grondtipes. In beide die rooibos- en heuningbosgrond was meer as $50 \%$ van die Acidobacteria geenvolgordes van onbekende spesies. Hierdie bevindings dui op die bestaan van 'n unieke nis waar nuwe spesies moontlik ontdek kan word.

Nota: 'n Seleksie van referaatopsommings: Studentesimposium in die Natuurwetenskappe, 31 Oktober - 1 November 2019 , Universiteit van die Vrystaat. Reëlingskomitee: Prof Rudi Pretorius (Departement Geografie, Universiteit van Suid-Afrika); Dr Hertzog Bisset (Suid-Afrikaanse Kernenergie-korporasie; Dr Ernie Langner (Departement Chemie, Universiteit van die Vrystaat) en Dr Wynand Nel (Departement Rekenaarwetenskap en Informatika, Universiteit van die Vrystaat). 